\title{
SOCIAL RESPONSIBILITY OF HIGHER EDUCATIONAL INSTITUTIONS - THE COMPARISON OF THE VIEW OF STUDENTS AND POTENTIAL STUDENTS
}

\author{
Lucie Kvasničková Stanislavská, Roman Kvasnička, Kateřina Kuralová, Klára Margarisová
}

Czech University of Life Sciences Prague

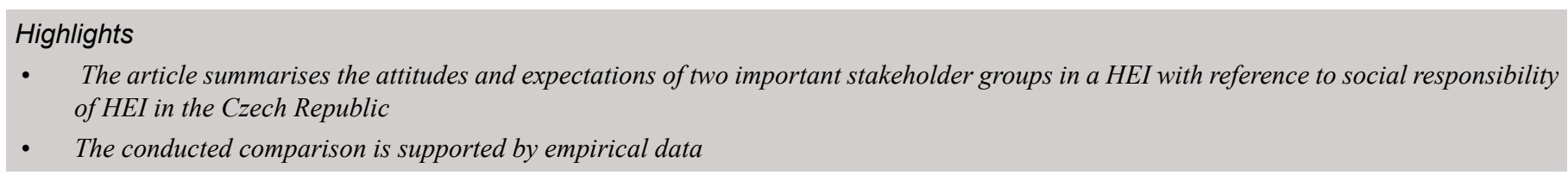

\section{Abstract}

Article type

Higher educational institutions (HEIs) in the Czech Republic seek to get quality and talented students. For the perception of HEI as quality institutions, it is essential that they behave in a socially responsible manner. Corporate social responsibility (CSR) is one of the useful tools to positively affect society and develop relationships with stakeholders. Current and future students are important stakeholders for HEIs. Through the method of focus groups the article chases up the knowledge and relationship to problems of social responsibility of universities between two important groups of interest - contemporary and potential students - and students' requirements on universities.

\section{Keywords}

Corporate social responsibility, higher education, stakeholders, focus groups, students, potential students

Full research paper

Article history

Received: September 19, 2014

Received in revised

form: December 20, 2014

Accepted: December 29, 2014

Available on-line: December 31, 2014

Kvasničková Stanislavská, L. et al. (2014) "Social Responsibility of Higher Educational Institutions - the Comparison of the View of Students and Potential Students", Journal on Efficiency and Responsibility in Education and Science, Vol. 7, No. 3-4, pp. 95-99, online ISSN 1803-1617, printed ISSN 1803-1617, doi: 10.7160/eriesj.2014.070308.

\section{Introduction}

Corporate social responsibility (CSR) has become an important part of firms' operations over the past decade. Social Responsibility has become an increasingly important concept both within the European Union and globally, and it has become part of the debate about competitiveness and sustainability in the globalization context (Vasilescu et al., 2010). Many organizations have increased their investments in CSR either voluntarily as part of their strategy and vision or as a result of pressure from activist shareholders. Many organizations also publish annual CSR reports that provide detailed information about their CSR activities and achievements or devote large sections of their annual reports to a description of their CSR activities (Deng, Kang and Low, 2013). In the European Union, the promotion of CSR also reflects the necessity to defend common values and increase the sense of solidarity and cohesion. Enterprises of all sizes, in cooperation with their stakeholders, can help by means of CSR to reconcile economic, social and environmental ambitions (Vasilescu et al, 2010).

\section{Current definitions}

'CSR is a continuous and long-term process guided by organisational and personal values. It is concerned with people (as stakeholders), the environment and organisational policies, and is influenced by political concerns. Adoption of CSR is often associated with monetary gain or profit for the initiator' (Isa, 2012: 335). 'Baron (2007) supported that corporate social responsibility has become an important part in the business strategy of a growing number of companies worldwide, since the performance of a business organization is affected by their strategies in the market, as well as non-market environments' (In Mustafa, Othman and Perumal, 2012: 898).

\section{Stakeholders in Corporate Social Responsibility}

Stakeholders play a key role in corporate social responsibility (Bearle and Means, 2002; Costa and Menichini, 2013; Murray and Vogel, 1997). According to Freeman's theory a stakeholder is anyone susceptible to be impacted by the goals of an enterprise and anyone that could be impacted by their realisation (Freeman 2010). The stakeholder theory is based on the necessity of producing outcomes, which can optimise the advantages for important stakeholders, without favouring only one stakeholder (Jones, 1999). The main point in the concept of corporate social responsibility is to understand the expectations of those, who can influence an organisation, and are influenced by an organisation (Steinerová, Václavíková and Mervart, 2008). Trnková (2004) states that the application of CSR principles is a process of building trust in target groups functioning within the organisation. An organisation becomes trusted, when it systematically tries to cooperate with stakeholders. Falck and Helbich (2007) assume that CSR can be applied in a strategic way for satisfying the requirements of each stakeholder. The management of an enterprise can use CSR as a normative instrument for making plans that will satisfy the shareholders, as well as stakeholders.

Costa and Menichini (2013) mention the negative impact that a lack of social responsibility of any given organisation has on stakeholders. Organisations that present themselves as socially responsible, yet are found not to be responsible by some stakeholders, can be severely damaged. Melé (2008) even claims that if the social responsibility of a company is understood in a broader sense, then the stakeholder theory can be considered as a theory of social responsibility, because it proposes a normative framework with reference to accountability. 
Social responsibility of higher educational institutions

The economic, political and social changes that took place over the past decades have had an impact also on the European higher education institutions, which have undergone an ample reform process meant to meet the new challenges they are facing. Globalisation, the knowledge society, innovation, the development of technologies, a growing emphasis on the market forces are among the key factors, which influence the universities' mission, organisation and profile, the mode of operation and delivery of higher education (Vasilescu et al., 2010). HEI increasingly need professional management structures, similar to corporate type organisations. A highly competitive market requires HEI to develop competences and skills that were previously not required. Specifically, this refers to resources management and management of the relations to students, or in matters of university branding (Michael, 2004). The mission of any HEI has been expanded beyond the framework of teaching and research. Nowadays, it includes service to the community in which the HEI is situated, partnership with surrounding communities and other stakeholders (Jongbloed, Enders and Salerno, 2008). Research shows that currently the important stakeholders are students, who are actually studying at a given HEI and potential students (Alves, Mainardes and Raposo, 2010; Chapleo and Simms, 2010; Kantanen, 2007).

The article follows and extends Kvasničková et al, (2014), the goal of which was to identify the attitude of contemporary university students to the problems of social responsibility of universities in the Czech Republic. This goal is extended by the identification of the attitude of potential university students to the mentioned problems.

\section{Materials and Methods}

The attitudes and expectations of students will be determined by the focus group method, recommended for this purpose by Mainardes, Alves and Raposo (2010). The focus group method is a useful and effective tool for determining collective opinions, values and faiths (Jayasekara 2012). Huston and Hobson (2008) describe the focus group method as a structured and planned group discussion designed in such a way as to gain a rational idea about a defined area of interest. The discussion should take place in pleasant and convivial surrounding.

Krueger and Casey (2000: 6-7), who have described the method in detail, mention its main aspects as follows:

- There should be 4 to 12 members in a focus group

- The main characteristic of the focus group is its homogeneity, with reference to the goal of the given study. It is the basic prerequisite for the functioning of a focus group. It ensures that the participants have the same mind-set from the very start of the discussion.

- Collecting qualitative data - the goal of the focus group is to collect data, with reference to the requirements of the researcher. By comparing the outcomes one can come to the desired conclusions, e.g. reaching a consensus, getting recommendation, or a choice of relevant decisions.

The discussion is prepared and led by the researcher. All the questions are formulated purposefully in logical sequences. The design of the questions is crucial for the research outcomes. Questions are classified from general to specific. The most relevant questions appear at the end of the research.
Veisová (2009) classifies typical questions raised during focus group discussions as follows:

- Opening questions that lead to the identification of common characteristics of participants.

- Introductory questions focused on the research theme, i.e. questions that define the issue that will be at the centre of discussions. Transitional questions that lead the conversation to the key issues.

- Key questions, crucial for the entire study.

- Final questions which close the discussion.

The structure of the focus group discussions outcomes refers to the type of questions (Veisová, 2009).

Specific types of questions are mentioned in Tab 1.

\begin{tabular}{|c|c|}
\hline $\begin{array}{l}\text { Typical } \\
\text { Questions }\end{array}$ & Specific types of questions \\
\hline $\begin{array}{l}\text { Identification } \\
\text { questions }\end{array}$ & $\begin{array}{l}\text { Identification of respondent (name } \\
\text { of HEI, year of studies) }\end{array}$ \\
\hline \multirow{2}{*}{$\begin{array}{l}\text { Introductory } \\
\text { questions }\end{array}$} & $\begin{array}{l}\text { Awareness of the concept of social } \\
\text { responsibility of HEI }\end{array}$ \\
\hline & $\begin{array}{l}\text { Awareness of socially responsible } \\
\text { activities of the HEI }\end{array}$ \\
\hline \multirow{3}{*}{ Key questions } & Ways of acquiring information \\
\hline & $\begin{array}{l}\text { Attitude to issues related to social } \\
\text { responsibility of the HEI }\end{array}$ \\
\hline & $\begin{array}{l}\text { Requirements and expectations with } \\
\text { reference to the HEI }\end{array}$ \\
\hline Final questions & Conclusion and amendments \\
\hline
\end{tabular}

Tab. 1: Structure of scenarios implemented during group discussions with focus group 'Current Students'

The main advantages of this method can be summarised as follows: the focus group is a quite inexpensive (Veisová, 2009) and fast method for collecting qualitative data (Huston and Hobson, 2008). A properly set up group can stimulate thought exchange amongst participants, ensuring that nothing will be omitted (Klein, Tellefsen and Herskovitz, 2007). Group interaction helps participants in developing and focusing their thoughts (Freeman, 2000).

For identifying the attitudes and requirements of current HEI students the above mentioned focus group method was used. The group discussions with HEI students had eight participants - five females and three males. There were group discussions held with potential university students studying their last year at secondary schools. Eight respondents participated in these discussions - for men and four women. At the time all respondents were decided to apply for a university in the following months.

The division of students according to their HEI is indicated in Tab 2. The division of potential university students of their type of the secondary schools indicated in Tab. 3 .

\begin{tabular}{|l|c|}
\hline Name of HEI & $\begin{array}{c}\text { Number } \\
\text { of respondents }\end{array}$ \\
\hline Czech University of Life Sciences Prague & 2 \\
\hline $\begin{array}{l}\text { Jan Evangelista Purkyně University in Ústí } \\
\text { nad Labem }\end{array}$ & 2 \\
\hline University of Economics, Prague & 2 \\
\hline Technical University of Liberec & 1 \\
\hline Masaryk University & 1 \\
\hline
\end{tabular}

Tab. 2: Respondents according to HEI 


\begin{tabular}{|l|c|}
\hline Type of secondary school & Number of respondents \\
\hline High school & 5 \\
\hline Grammar school & 3 \\
\hline
\end{tabular}

Tab. 3: Respondents according to type of secondary school

Tab 4. indicates students according to the year of studies at HEI.

\begin{tabular}{|l|c|}
\hline Year of study & Number of respondents \\
\hline 1. & 1 \\
\hline 2. & 2 \\
\hline 3. & 2 \\
\hline 4. & 2 \\
\hline 5. & 1 \\
\hline
\end{tabular}

Tab. 4: Respondents according to the year of studies at HEI

\section{Results}

\section{Awareness of the issue of social responsibility}

The initial question in the group discussion focused on identifying awareness of the issue of social responsibility, in general as well as with reference to HEI. The majority of respondents from contemporary students did not know the term. Some respondents of current students admitted that, the term is familiar to me, however, I do not know what it really means'. When requested to define to some extent what the term meant, they usually assumed that 'it had something to do with charity'. No one from the potential students knew the term.

The concept of social responsibility had thus to be explained. The EU definition as published in the Green Book - Promoting a European framework for corporate social responsibility (2001: 6) was cited: 'Corporate social responsibility is essentially a concept whereby companies decide voluntarily to interactions with stakeholders'. Social responsibility was also discussed in a broader context.

Another part of the discussion addressed the possibility of applying the concept of social responsibility in the conditions of Czech HEI. All respondents agreed that the concept can be applied at HEI and that HEI in the Czech Republic should act as socially responsible organizations. Even the majority of respondents from the group of potential students expressed the opinion that universities should also be social responsible. The participants stated that they would welcome these activities: 'It will make an impression on me, if I know that the school helps somehow', 'I would like it', 'I would appreciate it'.

Once the concept has been clarified, students could easily discern socially responsible activities in their HEI. Most often they thought of sports and cultural activities offered to employees and students (e.g. 'ball dances', 'concerts', 'festivals', 'sports facilities'), sporting events for the public (e.g. 'we offer the sporting grounds of the Department of Physical Education for use by the public') as well as ecologically minded activities (e.g. 'we separate waste'). The most frequent socially responsible activities that the secondary school students could recall were also cultural and sport events for students and the public: 'I know about festivals at universities'. The students also noticed ecological activities of universities: 'During open day I saw that many universities sort waste'.

\section{Information channels}

Ways in which students get information about socially responsible activities at their HEI, have also been investigated.
The most often cited information channel were posters in the campuses. Students also mentioned that the teachers informed them during their classes.

Students thought that they have enough information about the abovementioned activities of social responsibility ('I think that information is available when someone is looking for it and he can find it') and they don't need to obtain information in another way.

All secondary school students, who took part in the group discussions, considered gaining information from universities as insufficient. They found out about socially responsible activities, which they knew, from their friends ('I've never found anything about it on university websites', 'I think that these activities aren't promoted in the media at all'). In general the last year students evaluate the university websites negatively ('there is information only about the fields of study, I've never found, what I've been looking for', 'the websites didn't help me a lot', 'it is difficult to orientate in the websites and I've never found what I've looked for'). Except for the information about socially responsible activities, that most students would be interested in (there was only one student, who did not show interest in this problems - 'my main interest at the moment is the GCSE exam'), the students lacked information about entrance examinations (' $I$ was searching how many points do I need, I was interested in subjects in particular fields of study, I want to decide according to $i t$ '). The students appreciate open days of individual universities, where the majority of them took part in ('the best way is, when also the students are present, I'm interested in their experience with the university'). They suggest to extend the potential of open days by handing out leaflets with detailed information ('I thoroughly studied everything that was for nothing', 'I would welcome, however I didn't get any'). The students would next appreciate delegations of university representatives at their secondary schools, especially when also the university students would participate ('it is more trustworthy', it will influence me a lot when choosing a university').

\section{Involvement of students in socially responsible activities at $\mathrm{HEI}$}

Controversies arose around this issue. One section of current students was willing to take part in socially responsible activities of the HEI in their free time, provided it 'had a meaning' and provided they found the project 'beneficial'. Another section refused to take part, with explanations ranging from 'I have enough of my own work', or 'I prefer to work and make money'. If a socially beneficial project would be implemented as a part of their curricula, all respondents replied that they would take part.

Secondary school students' attitude to socially responsible activities was more definite. In case that they are accepted to a university, the majority of students would not refuse to join in a socially responsible activity. Most frequently they would welcome if the activity is connected with their study ('so that I can later write it in my CV', 'I will participate if it is connected with my study'). A small part represented by women will be ready to take in the activities even if they are not connected with their study ('if it is meaningful, it doesn't have to have something to do with my study', 'I wouldn't mind to sacrifice my own free time').

\section{Requirements of students}

Key issue addressed during group discussion. Students would require more facilities, such as reading rooms, access to internet, a user friendly IT system, etc. They would also want more 
cooperation between HEI and the industry, more specialists involved in teaching, the possibility to have internships at companies, possibility to write one's thesis while doing an internship, etc. Students would of course require adequate housing and meals to be provided. Thirty-six student requirements have been generated from our survey. The requirements were divided into six groups:

- Students' technical and administrative requirements,

- Cooperation between HEI and the industry,

- Triple Bottom Line Activities,

- Welfare requirements,

- Possibilities for language skills improvement,

- Free time activities for students

The requirements of potential students are current to those of contemporary students. However they put greater emphasis on an easier way of getting information from universities (open days, clear websites, helpful attitude of the staff, who come into contact with university applicants, etc.) and opportunities for foreign language improvement such as high level of language subjects, the possibility to study abroad and cooperation with foreign universities. There were thirty-five requirements identified in this group. The requirements were divided to seven groups:

- Technical facilities and open communication,

- Cooperation between HEI and the industry,

- Triple Bottom Line Activities,

- Welfare requirements,

- Possibilities for language skills improvement,

- Free time activities for students

- Admission Process through SCIO tests (National Comparative Exams)

\section{Discussion}

Interaction between HEI and their stakeholders is a relatively new concept within academia, however it has been increasingly acknowledged by HEI Boards as well as by academics specialised in the area of HEI management (Alves, Mainardes and Raposo, 2010).

Despite the growing interest in the issue of universities stakeholder the current research are focus only on the first step in analysing universities stakeholders - to the identification of relevant interest groups. Brown (1999) in his article identifies the most important stakeholders: students, government, employers - teaching staff. Moreover, Brown highlights the relationships between an HEI and these stakeholders as a 'survival route for this type of institutions'.

The concept of social responsibility is widespread in the commercial sector. However the research findings indicate that majority of respondents are not familiar with the concept of CSR. For current and potential students concept of CSR represents activities as concert, festivals etc.

The research focusing on the next step in the analysis of stakeholders, i.e. identifying the requirements of important stakeholders for HEIs, is missing. This kind of research is missing despite the fact that the satisfaction of students is crucial for HEIs. To identify the requirements of the stakeholders is important for the modern HEI, in accordance of Wiliams (2002). He sets that the students' feedback is necessary for HEI. His study findings confirmed the importance of measuring student satisfaction as a relevant HEI management tool. According to our findings the HIES should complete and make more clear their websites. So the potential students can find necessary information.

However the researches in this area are primary focused on the customers' perceptions of CSR concept in companies (Trapero, Lozada and García, 2010). Other studies are focused on the question: how big influence the stakeholders have on CSR activities at corporations (Park,Chidlow and Choi, 2014). But the identification of stakeholders' requirements are missing in these studies. This article presents an extended view of social responsibility associated primarily with the requirements of HEI's stakeholders.

\section{Conclusion}

The article summarises the attitudes and expectations of two important stakeholder groups in a HEI with reference to social responsibility of HEI in the Czech Republic. The group discussions indicates that today`s students and potential students do not have enough theoretical knowledge of the concept of corporate social responsibility. Their understanding of the concept is limited, and takes only sports and social events into consideration. A section of understands the concept to be related to ecological activities of their HEI. As to personal involvement of students in socially responsible activities, the study has shown some incongruity. Some students would be willing to get involved during their free time in socially responsible activities, provided such activity would be considered as meaningful by them. Compared to this, potential students are willing to take part in the socially responsible activities.

Students considered current dissemination of information about the social responsibility of HEI as satisfactory in case of active involvement. Passive involvement comes through posters and flyers, or through information shared by the teacher during a course. Secondary school students express their dissatisfaction with the way of communication in this field. In general potential students are dissatisfied with the way of getting information from universities. They often consider university websites as unclear. They would appreciate a more active approach to getting information from universities, e.g. by the delegations of university representatives at secondary schools.

At the end of the focus group sessions the requirement of students with reference to social responsibility of the HEI, were analysed. On the basis of respondent's answers a list of relevant requirements of students on the HEI was drawn. This list will be used in subsequent quantitative research. The requirements will be tested using the 5 point Lickert' Chart. In a survey, using factor analysis, various factors will be identified and evaluated with reference to benefits generated for each stakeholder.

\section{References}

Alves, H., Maninardes E.W. and Raposo, M. (2010) 'A Relationship Approach to Higher Education Institution Stakeholder Management', Tertiary Education and Management, vol. 16, no. 3, pp. 159-181, http://dx.doi.org/10.1080/13583883 .2010 .497314

Baron, D. (2007) 'Corporate social responsibility and social entrepreneurship', Journal of economics and Management Strategy, vol. 16, no. 3 pp. 683-717, http://dx.doi.org/10.1111/ j.1530-9134.2007.00154.x

Bearle, A. and Means, G. (2002) The Modern Corporation and Private Property. 4. print. New Brunsvick: Transaction Publishers, 2002. 
Brown, S. (1999) A systemic perspective on higher education in the United Kingdom. Systems Research and Behavioral Science, vol. 16, no. 2, pp. 157-169

Chapleo, C. and Simms, C. (2010) 'Stakeholder analysis in higher education', Perspectives: Policy and Practice in Higher Education, vol. 14, vo 1, pp. 12-20, http://dx.doi. org/10.1080/13603100903458034

Costa, R. and Menichini, T. (2013) 'A multidimensional approach for CSR assessment: The importance of the stakeholder perception', Expert Systems with Applications, vol. 40, no. 1, pp. 150-161, http://dx.doi.org/10.1016/j.eswa.2012.07.028

Deng, X., Kang, J. and Low, B.S. (2013) 'Corporate social responsibility and stakeholder value maximization: Evidence from mergers', Journal of Financial Economics, vol. 110, no. 1, pp. 87-109. http://dx.doi.org/10.1016/j.jfineco.2013.04.014

European Communities (2001) Green Paper Green Paper Promoting a European framework for 358 ERIE 2014 corporate social responsibility. [Online], Available: http://eur-lex.europa. $\mathrm{eu} /$ legalcontent $/ E N / T X T /$ ? uri=CELEX:52001DC0366 [10 May 2014]

Falck, O. and Helbich, S. (2007) 'Corporate social responsibility: Doing well by doing good', Business Horizons', vol. 50, no. 3, pp. 247-254. http://dx.doi.org/10.1016/j.bushor.2006.12.002

Freeman, E. (2010) Strategic Management: A Stakeholder Approach. Cambridge: Cambridge University Press.

Huston, S.A. and Hobson, E.H. (2008) 'Using focus groups to inform pharmacy research'. Research in Social and Administrative Pharmacy, vol. 4, no. 3, pp. 186-205, http:// dx.doi.org/10.1016/j.sapharm.2007.09.001.

Isa, S., M. (2012) 'Corporate Social Responsibility: What Can We Learn From Stakeholder'. Procedia-Social and Behavioral Sciences, vol. 65, pp. 327-337, http://dx.doi.org/10.1016/j. sbspro.2012.11.130

Jayasekara, R., S. (2012) 'Focus groups in nursing research: Methodological perspectives', Nurs Outlook, vol. 60, no. 6. pp. 411-416, http://dx.doi.org/10.1016/j.outlook.2012.02.001

Jones, M. T. (1999) 'The Institutional Determinants of Social Responsibility', Journal of Business Ethics, vol. 20, no. 2, pp. 163-179. http:// dx.doi.org/10.1023/A:1005871021412

Jongbloed, B., Enders, J. and Salerno, C. (2008) 'Higher education and its communities: Interconnections, interdependencies and research agenda', Higher Education, vol. 56, no. 3, pp. 303-324, http://dx.doi.org/10.1007/s10734-008-9128-2

Kantanen, H. (2007) 'Community Relationships and the Practice of Public Relationships in Higher Education', Tertiary Education and Management, vol. 13, no. 1, pp. 47-59, http:// dx.doi.org/ 10.1080/13583880601151254

Klein, E.E., Tellefsen, T. and Herskovitz, P.J. (2007) 'The use of group support systems in focus groups: Information technology meets qualitative research', Computers in Human Behavior, vol. 23, no. 5, pp. 2113-2132. http://dx.doi.org/10.1016/j. chb.2006.02.007

Krueger, R.A. and Casey, M.A. (2000) Focus Groups: A practical Guide for Applied Research, Thousand Oaks, CA: SAGE.

Kvasničková Stanislavská, L., Kvasnička, R., Kuralová, K. and Margarisová, K. (2014) 'Social Responsibility of higher educational institutions - The students' view'. 11th International conference on Efficiency and Responsibility in Education 2014.
Mainardes, E.W., Alves, H. and Raposo, M. (2010) 'An Exploratory Research on the Stakeholders of a University", Journal of Management and Strategy. vol. 1, no. 1, http://dx.doi. org/10.5430/jms.v1n1p76

Melé, D. (2008). 'Corporate Social Responsibilities Theories',The Oxford Handbook of Corporate Social Responsibility. New York: Oxford University Press. http:// dx.doi.org/10.1093/oxfordhb/9780199211593.003.0003

Michael, S.O. (2004) 'In search of universal principles of higher education management and applicability to the Moldavian higher education system'. The International Journal of Educational Management, vol. 18, no. 2, pp. 118-137. http:// dx.doi.org/10.1108/09513540410522252

Murray, K.B. and Vogel, C.M. (1997) Using a Hierarchy-ofEffects Approach to Gauge the Effectiveness of Corporate Social Responsibility to Generate Goodwill Toward Firm: Financial versus Nonfinancial Impacts. Journal of Business Research. vol. 38, no. 2, pp. 141-159. http://dx.doi.org/10.1016/ S0148-2963(96)00061-6

Mustafa, S.A., Othman, A.R. and Perumal, S. (2012) 'Corporate Social Responsibility and Company Performance in the Malaysian Context", Procedia - Social and Behavioral Sciences, vol. 65, pp. 897-905. http://dx.doi.org/10.1016/j. sbspro.2012.11.217

Park, B.I., Chidlow, A. and Choi, J. (2014) 'Corporate social responsibility: Stakeholders influence on MNEs' activities', International Business Review, vol. 23, no. 5, pp. 966-980 http:// dx.doi. org/10.1016/j.ibusrev.2014.02.008

Steinerová, M., Václavíková, A. and Mervart, R. (2008) Společenská odpovědnost firem, průvodce nejen pro malé a střední podnik. Praha: Business Leaders Forum,

Trapero, F.G.A., Lozada, V.C.M. and García, J.G. (2010) 'Consumers and their buying decision making based on price and information about corporate social responsibility (CSR). Case study: Undergraduate students from a private university in Mexico', Estudios Gerenciales. 2010, vol. 26, no. 117, pp. 103118. http://dx.doi.org/ 10.1016/S0123-5923(10)70136-4

Trnková, J. (2004) Společenská odpovědnost firem - kompletní průvodce tématem a závěry z průzkumu v ČR, Praha: Business Leaders Forum.

Vasilescu, R., Barna, C., Epure, M. and Baicu, C. (2010) 'Developing university social responsibility: A model for the challenges of the new civil society', Procedia Social and Behavioral Science, vol. 2, no. 2, pp. 4177-4182, http://dx.doi. org/10.1016/j.sbspro.2010.03.660

Veisová, E. (2009). Možnosti a dusledky kombinace metod v sociologickém výzkumu se zretelem na metody focus groups a internetového výzkumu. Prague: $\mathrm{PhD}$ Thesis. Institute of Sociological Studies, Faculty of Social Sciences, Charles University, Prague.

Williams, J. (2002) The student satisfaction approach: Student feedback and its potential role in quality assessment and enhancement. Paper presented at the 24th EAIR Forum, Prague, Czech Republic. 